\title{
FRICTION RIDGE IMPRESSIONS ON DAUB FRAGMENTS FROM THE EARLY BRONZE AGE SETTLEMENT IN BRUSZCZEWO
}

\begin{abstract}
Studies of friction ridge impressions on archaeological artefacts are only very rarely published due to the high rate of destruction of such traces or leaving out such information of the analyses of archaeological material. The article presents the results of examinations of friction ridge impressions discovered on daub fragments from the Early Bronze Age settlement in Bruszczewo, dated to ca. 2000-1600 BC. The fragments were closely related to remains of buildings recorded in the course of excavations. Out of five instances of friction ridge impressions, two enabled the estimation of the age of the persons who had left them. It was determined that they probably were young people. The results cast new light on the role of children/youth in prehistory.
\end{abstract}

KEY WORDS: Fingerprints - Early Bronze Age - Únètice culture - Fortified settlement - House constructions

\section{INTRODUCTION}

The history of studies of ancient friction ridge impressions goes back to the late $19^{\text {th }}$ and early $20^{\text {th }}$ centuries. One of the first discoveries in this area was made by Henry Faulds, a Scottish doctor and amateur archaeologist who worked in Japan. He published his findings on prehistoric Japanese ceramics in Nature in 1880 (Faulds 1880: 605, Cummins 1942: 473, Jägerbrand et al. 2006: 9). The first archaeologist to document a large amount of pottery bearing friction ridge impressions was W. F. Badé (Branigan et al. 2002), who excavated at Tell en-Nasbeh in Palestine. Friction ridge impressions were recorded mostly on pot handles and the inner surfaces of clay lamps. Their study revealed that almost all wares had been made by the same potter (Jägerbrand 2007: 19).

Furthermore, many friction ridge impressions were recorded in Greece, for instance on Minoan pottery (Åström 2007). In northern Europe, such finds date

Received 13 September 2017; accepted 5 March 2018.

(C) 2019 Moravian Museum, Anthropos Institute, Brno. All rights reserved.

DOI: https://doi.org/10.26720/anthro.18.03.05.1 
back to the Neolithic. At the Siretorp site, Sweden, a series of pottery bearing friction ridge impressions was identified. Besides indicating which hand had left a given friction ridge impression, the age of the person making it was determined. It transpired that most of the friction ridge impressions had been left by teenagers (Jägerbrand et al. 2006: 16). In Tessin, Germany, the study of friction ridge impressions on pottery suggested that they had been made by specialized craftsmen related by blood (Primas 1975).

The oldest find of this type has to be considered a Venus figurine from the Dolní Věstonice site in Czech Republic, dated to ca. 25000 BP (Králík et al. 2002). A friction ridge impression on the figurine is believed to have been made by a young woman/girl (Králík et al. 2002: 112-113). One of the most unique specimens of ancient friction ridge impressions, however, comes from the Hulin-U Isidórka site in Czech Republic. The specimen owes its uniqueness to the material on which impressions have survived. They were left on spiral bronze rings (Noppenringe) dated to the Early Bronze Age and found in graves, most likely of a man and woman (Peška et al. 2005: 83-86). Corrosion caused by soil humidity and body decomposition produced patina, which has turned out to be a perfect carrier for friction ridge impressions (Peška et al. 2005, Králík, Nejman 2007: 8).

Polish archaeology has little to say on friction ridge impressions left on artefacts. The professional literature mentions only two such cases. The first involves impressions made on Late Bronze and Early Iron Age pottery, coming from the Kunice site (Mierzwiński 2003). Pottery shards from that site were characteristically ornamented with finger imprints. From a morphometric analysis, the author of the study concluded that children, most likely girls, were responsible for making the ornament (Mierzwiński 2003: 22-24). The work of the cited author met with criticism (Dąbrowski, Mogielnicka-Urban 2004). What came under attack was above all the use of the anthropometric features of current populations for comparison. The second case involves pottery bearing friction ridge impressions from the period of Roman influence found in Jakuszowice. Its examination set the age of potters approximately at above 20 years (Białek, Rodzińska-Nowak 1995: 81-82).

So small number of publications on friction ridge impressions found on archaeological artefacts results not only from the rarity of such finds, but also the omission of relevant information from the descriptions of ceramic materials. Keeping this in mind, the friction ridge impressions on daub from Bruszczewo can be considered the oldest recorded finds of this kind in the lands of present-day Poland.

\section{The use of dactyloscopy with regard to prehistoric artefacts}

Friction ridge impressions on archaeological artefacts can be examined to estimate the age of the person who left them and, albeit less often, his/her sex, morphological features or ethnicity (Cummins et al. 1941, Kamp et al. 1999, Králík, Novotný 2003). We also know of studies to determine if friction ridge impressions on different finds from the same site or interconnected sites have a common source (Branigan et al. 2002: 49, Jägerbrand 2007: 19). Besides the methods of determining the common origin of different friction ridge impressions, the most reliable findings are produced by the methods of estimating the age of the person who left them. They are based on the growth of the breadth of epidermal ridges that takes place with human growth and help distinguish between ridge impressions originating from children and adults. Moreover, in the case of impressions left by children, they allow for estimating the age of the child (Kamp et al. 1999, Králík, Novotný 2003). Any findings as to the sex of the person leaving the impression are, alas, less reliable, because the variation ranges of the epidermal ridge breadth of men and women considerably overlap (Ohler, Cummins 1942, Králík, Novotný 2003). Similar limitations affect the methods of making inferences about the morphological features or ethnicity of the persons who left friction ridge impressions. The matters are made worse by the frequent shrinkage of archaeological material bearing such impressions (Kamp et al. 1999). Finally, another shortcoming is drawing conclusions on prehistoric human populations using models developed for present-day populations (Dąbrowski, MogielnickaUrban 2004).

\section{Fortified settlement in Bruszczewo}

Bruszczewo lies on a flat, slightly undulating end and bottom moraines located in the Warsaw-Berlin ProGlacial Stream Valley (Figure 1). As a result of geological processes, the land surface at the site took on the form of a promontory (Hildebrandt-Radke 2010), clearly dominating the surrounding landscape. In the Early Bronze Age, the promontory was surrounded by lake waters on three sides. On this 
landform, about $2000 \mathrm{BC}$, a fortified settlement was located by an Únĕtice culture population group and given complex fortifications. The uniqueness of the site is underscored by excellent conditions for the preservation of timber structures, which have survived in its peat portion (Jaeger 2015, 2016: 51-57).
The first information on excavations on the Bruszczewo promontory dates back to the 1960 s (Pieczyński 1985, Czebreszuk et al. 2004: 20, Silska 2012). In the 1990s, excavations were resumed to verify earlier findings (Czebreszuk, Müller 2004, Czebreszuk, Müller 2015, Müller et al. 2010, 2015).

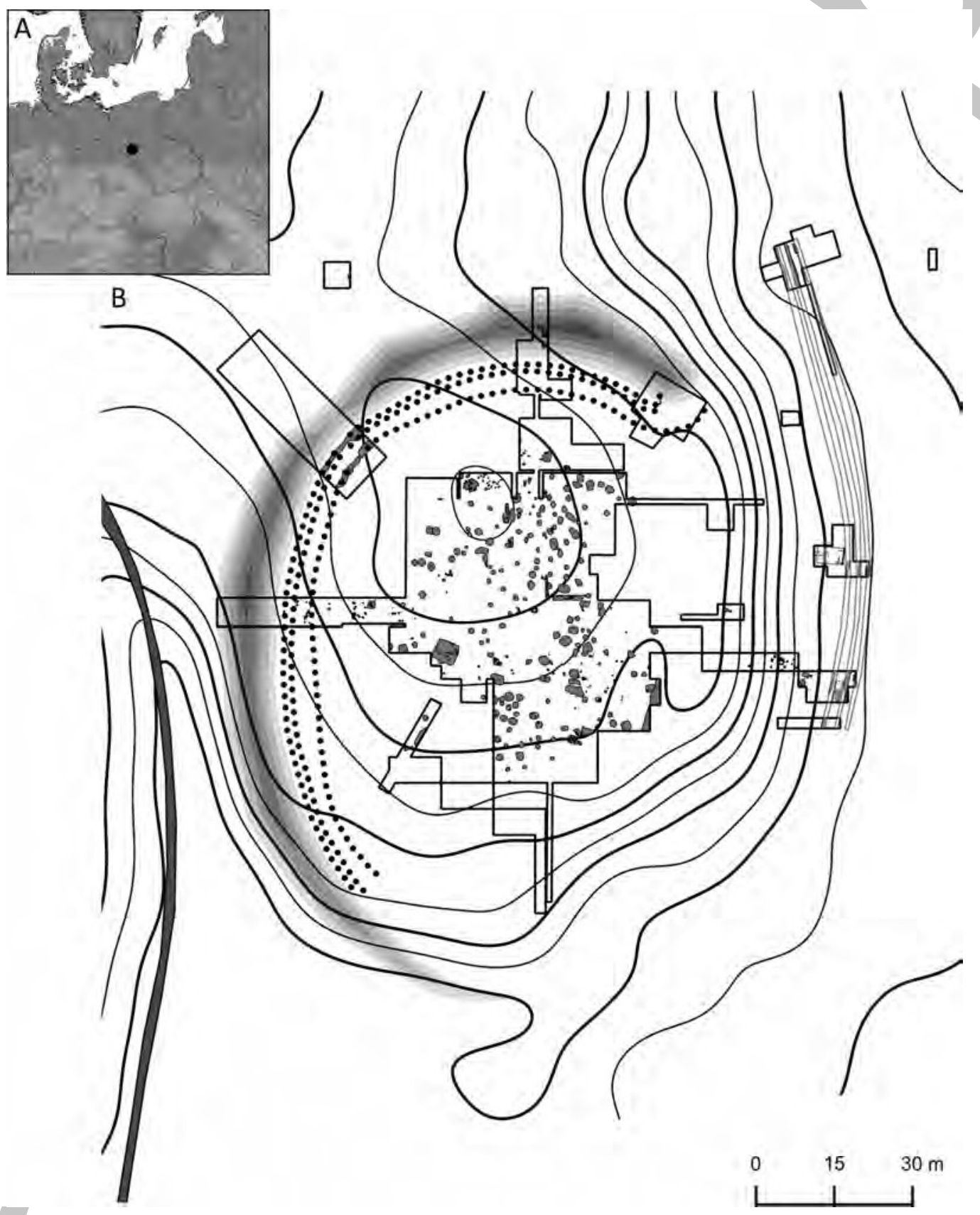

FIGURE 1: A - Bruszczewo, site 5. Location of the site in Central Europe, B - Plan of the Early Bronze Age settlement with excavated elements of the inner layout and fortifications. 
The second stage of excavations produced new information on the Early Bronze Age settlement. Extending the range of the excavations (for instance, beginning work in the peat zone) and applying the state-of-the-art research methods (including magnetometry, aerial photography, geochemical analyses) expanded the information pool and helped interpret this period of prehistory in greater detail. The information gathered so far shows that the settlement was built ca. $2000 \mathrm{BC}$, with the first stage being the construction of the main line of fortifications, consisting of a ditch (up to wide and up to approx. deep) and at least two rows of oak palisades. The fortifications cut off the promontory from the morainic plateau, making it an artificial island. The settlement was used until ca. $1600 \mathrm{BC}$ and witnessed several phases of reconstruction and expansion. One of them was the construction of fortifications on its eastern side in the early $18^{\text {th }}$ century BC. Moreover, throughout its existence the settlement featured a metallurgic workshop (which is evidenced by the finds of sandstone mould, tuyères and crucibles) and another one in which bone and antler were processed. Amber beads were found within its perimeter as well (Czebreszuk, Müller 2015).

Daub fragments bearing friction ridge impressions from the Early Bronze Age settlement in Bruszczewo. Context data.

For a friction ridge impression to survive until today, it had to be left on a suitable material under favourable circumstances (Králík, Nejman 2007) and
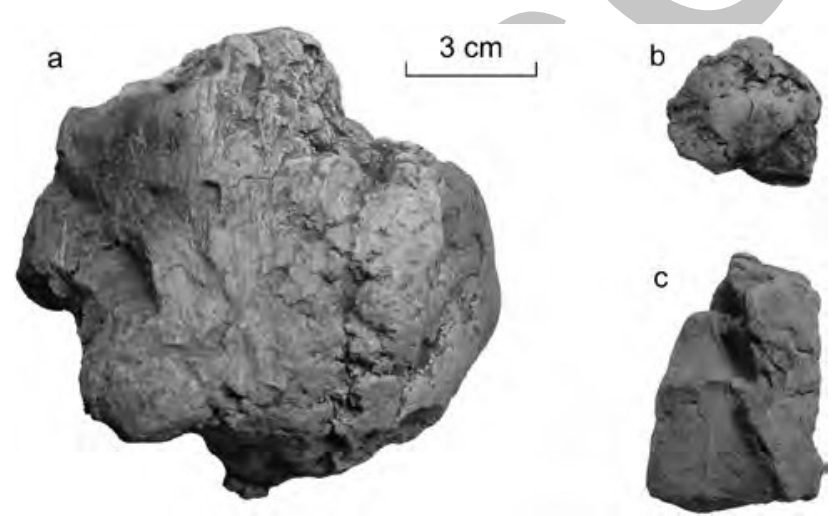

FIGURE 2: Impressions of structural elements on daub fragments. a - daub fragment from trench $\mathrm{L}, \mathrm{b}$ - daub fragment from trench T, c - daub fragment from trench X. deposited in a favourable environment. Owing to its plasticity, clay has the best properties in this respect (Králík et al. 2008: 3).

Frequently, friction ridge impressions are left unintentionally while forming vessels or building houses (wall pugging). Friction ridge impressions on building-related materials (such as daub) are very rare. We only know of friction ridge impressions left purposefully (?) on medieval bricks (Králík et al. 2008). This is so because for friction ridge impressions to be preserved, clay must be fired. In the case of Bruszczewo daub fragments, most of them bear traces of exposure to a high temperature. It is hard to tell if this is a result of a construction technology or a single incident (fire?).

\section{Location and archaeological context of daub fragments bearing friction ridge impressions}

The daub fragments bearing friction ridge impressions were found within the cultural layer among archaeological features (within trenches $\mathrm{H}$, L, T and X, Silska 2012: 216, Fig. 20: 38, Figure 3.3). The concentration analysis of features with daub shows that they were concentrated in the settlement centre, within the trenches excavated in the 1960s (Jaeger, Stróżyk 2015: 289). Moreover, in the neighbourhood of trenches $\mathrm{L}$ and $\mathrm{T}$, the greatest concentration of ceramic material (Silska 2012: 253, Fig. 147, cf. Figure 3.4) and daub from outside of features (Silska 2012: 216, Fig. 124, 289, cf. Figure 3.5) was found. What is more, inside trench $\mathrm{A}$, the largest number of stone and bone artefacts were recorded (Drejer 2006: 67, Fig. 20, 71, Fig. 23, 73, Fig. 25, cf. Figure 3.6, 3.7), which may suggest that this portion of the settlement was the venue of some economic or production activities.

\section{CHRONOLOGY}

Within the named trenches, mainly Early Bronze Age features are found (Czebreszuk 2015, Fig. 4.2). Their chronology was determined, relying on ceramic material and absolute dating (Silska 2012: 241, Czebreszuk 2015, Tabl. 4.1). On account of this data, it is reasonable to associate the daub fragments with the Early Bronze Age period of activity on the site. It is not possible to determine when exactly they were made within this period, hence it has to be accepted that it was some time between 2000 and 1600 BC. 


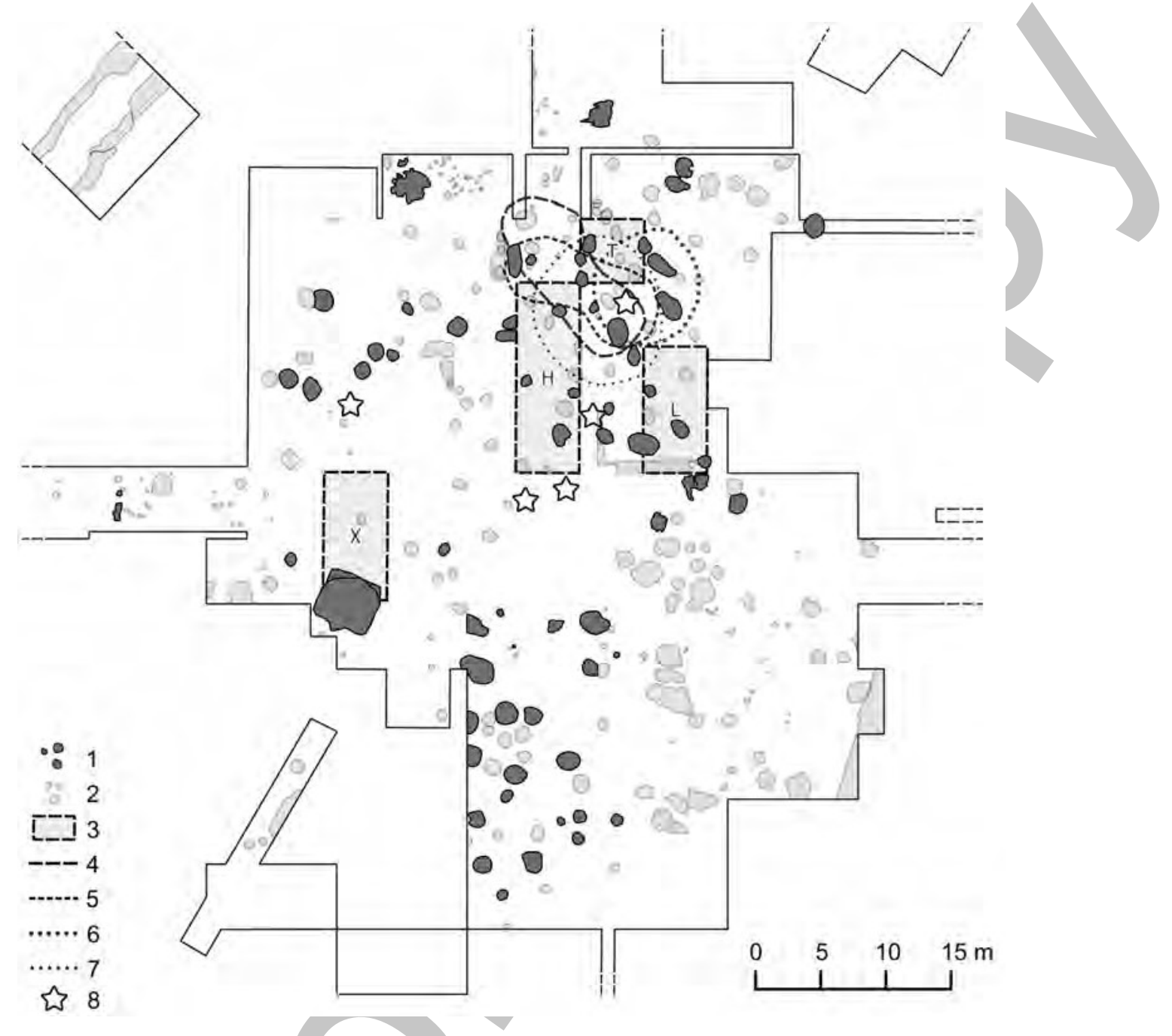

FIGURE 3: Bruszczewo, site 5. Overall plan of archaeological features. 1 - features with daub, 2 features without daub, 3 - trenches with daub fragments bearing friction ridge impressions, 4 concentration of pottery, 5 - concentration of daub from outside of features, 6 - concentration of stone artefacts, 7 - concentration of bone artefacts, 8 - hearth.

\section{Daub fragments and Early Bronze Age construction}

The daub fragments under consideration bear also the impressions of structural elements of buildings (Figure 2). There are traces that can be attributed to flat elements (such as boards, Figure 2a) as well as impressions of twigs (Figure $2 b$ ), characteristic of wattle and daub structures (Jaeger, Stróżyk 2015: 296). In the Únĕtice culture construction, post-structure huts with wattle walls most probably dominated (Stróżyk 2015: 392).

Relying on the layout of Early Bronze Age features in which large amounts of daub occur and the distribution of archaeological artefacts (see above), it can be tentatively claimed that within trenches $\mathrm{L}$ and $\mathrm{T}$ a functionally specific structure once stood (Figure 3). Furthermore, within the reconstructed feature, a hearth surrounded by a rim of stones, one of the very few at the settlement, was recorded, pointing to a space related to household activities (Silska 2012: 253). Measuring approximately $6 \times 9$ metres, the building had an apseshaped wall. Analogous Early Bronze Age huts are found in southern Germany (Figure 4). In a broader context, it cannot be ruled out that hall-type houses were also built, measuring $6 \times 24$ metres, characteristic of the Únětice 
culture construction (cf. Figure 3.1, Schefzik 2010: 339, example: Březno type). Unfortunately, the range of trenches prevents this hypothesis from being born out. The remains of such structures are found chiefly in the Czech Republic and Germany (Stuchlík 2000, Schefzik 2006, 2010, Zeitler 2006, Bláhová-Sklenářová 2013).

In trench $\mathrm{X}$, feature $80 / 78 \mathrm{P}$ is located in the neighbourhood of which a daub fragment bearing a friction ridge impression was discovered. The slightly trapezium-shaped structure, measuring approx. $4 \times 4$ metres and featuring a hearth (Czebreszuk 2015: 180-181, Stróżyk 2015: 392-393), is probably the remains of a hut sunk into the ground (Stróżyk 2015: 393, Fig. 9.7). The Unétice culture is known for the remains of buildings partially sunk into the ground. Their structure may have rested on posts (e.g. Radłowice, Lasak 1991).

\section{The analysis of friction ridge impressions on daub frag- ments from Bruszczewo}

The studied set comprises five friction ridge impressions on four daub fragments (Figure $5 a-e$ ). One
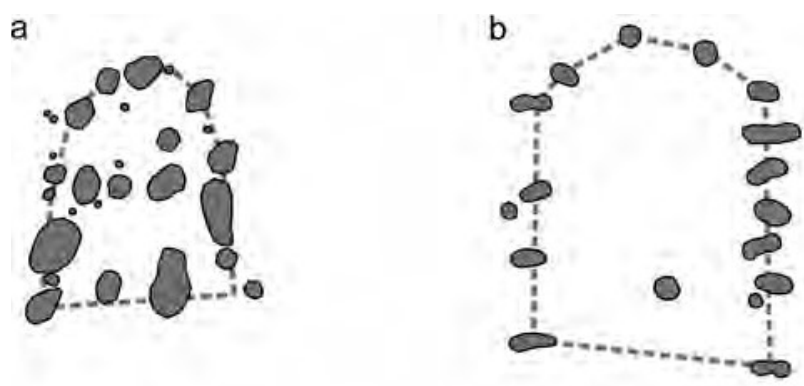

C
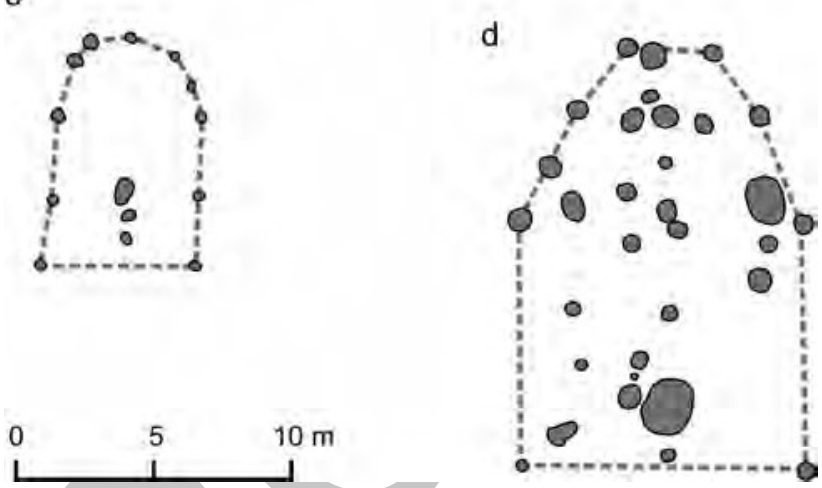

FIGURE 4: Examples of house forms with one semicircular wall. a - Bruszczewo, Wielkopolska, b - Izier-Le Joannot, Bourgogne, c - Dornach, Lkr. München, d - Zuchering, Stadt Ingolstadt. (After Schefzik 2010: 336, abb. 3A). of the impressions (Figure 5a) was documented earlier when the materials collected in the 1960s were being processed (Silska 2012: 275, Fig. 165). It has been assumed that all the impressions come from ridges on hands. In the entire collection of Bruszczewo daub fragments, there are many specimens bearing impressions of wooden rods and other structural elements, which should be interpreted as the remains of walls. Floor remains of compacted and fired clay are not known from Bruszczewo, which makes it absolutely impossible for the impressions to have been left by ridges on feet. In our opinion, one impression is probably a fingerprint (Figure 5a), while there is not enough evidence to determine the part of a hand that left other impressions. In the case of two impressions (Figure $5 a, 5 b$, from trenches L and T), the breadth of ridges could be measured (using LAS software and microscopic photographs taken with a stereoscopic microscope Leica $\mathrm{M} 165 \mathrm{C}$ and a camera Leica DFC450). We counted the ridges along predefined lines ( $5 \mathrm{~mm}$ long or shorter) that were drawn at several places of each impression, and then divided the lengths of the lines by the ridges counts. Accordingly, the breadth of the ridges was quantified four times for one impression and five times for the other impression (Table 1). The weighted average breadth was $0.427 \mathrm{~mm}$ (Figure $5 b$ ) and $0.383 \mathrm{~mm}$ (Figure $5 a$ ), respectively.

To estimate the age of the persons who left the impressions, three regression equations were used: after Kamp et al. (1999) modified by Králík (2000), after Loesch and Czyżewska (1972) modified by Králík and Novotny (2003) and after Králík and Novotny (2003) In the case of the impression on a small daub fragment (Figure 5a), the age of the person who had left the print was estimated at about 12 years (person A), with all the equations producing very similar results (Table 1). The age of the person who had left the impression on a large daub fragment (Figure $5 b$ ) was estimated at 14-16 years (person B). The use of the equation according to Loesch and Czyżewska (1972), modified by Králík and Novotny (2003), produced the age estimate of about 16 years, while the two other methods suggested the age of about 14 years (Table 1).

Thus, the results support the conclusion that the friction ridge impressions on the studied daub fragments originate from children or youth. This conclusion, however, bears some risk of error. The major source of uncertainty is the use of regression models that have been developed from data collected for present-day populations. Since the conclusions relate to the representatives of prehistoric populations, who were 
a

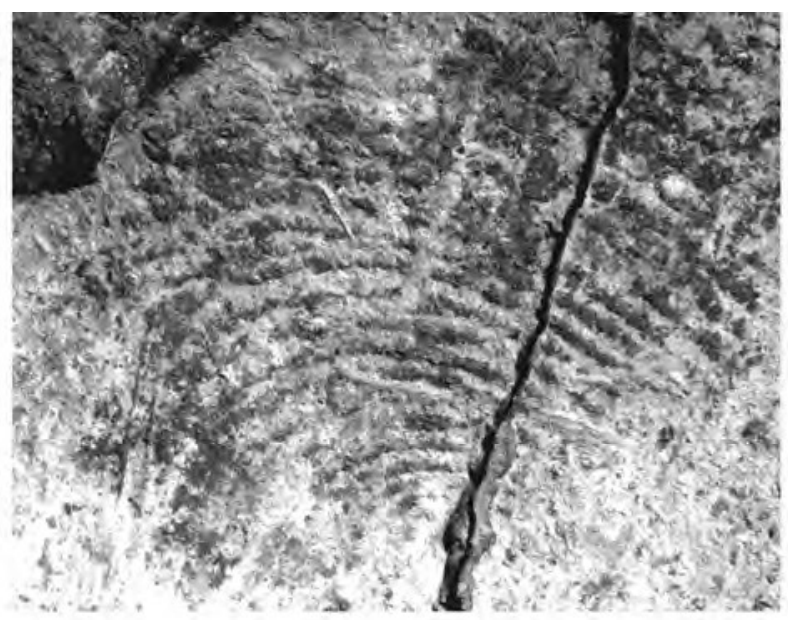

c

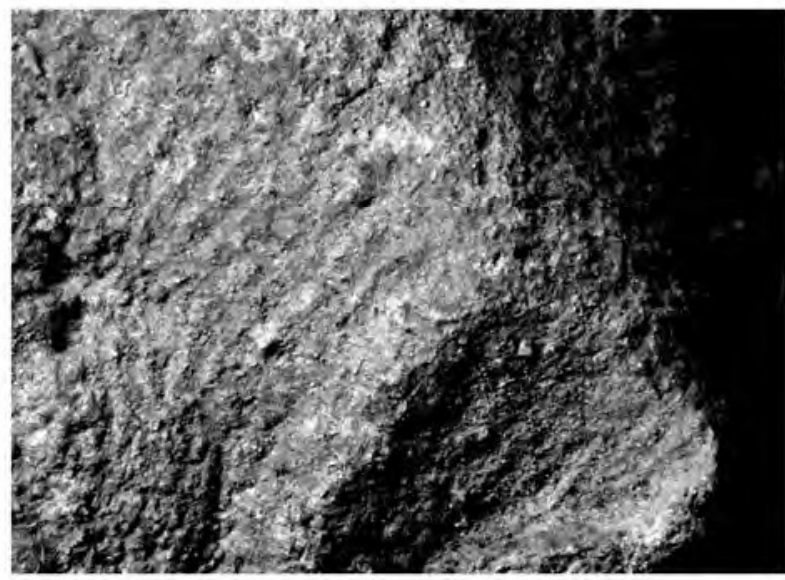

$b$

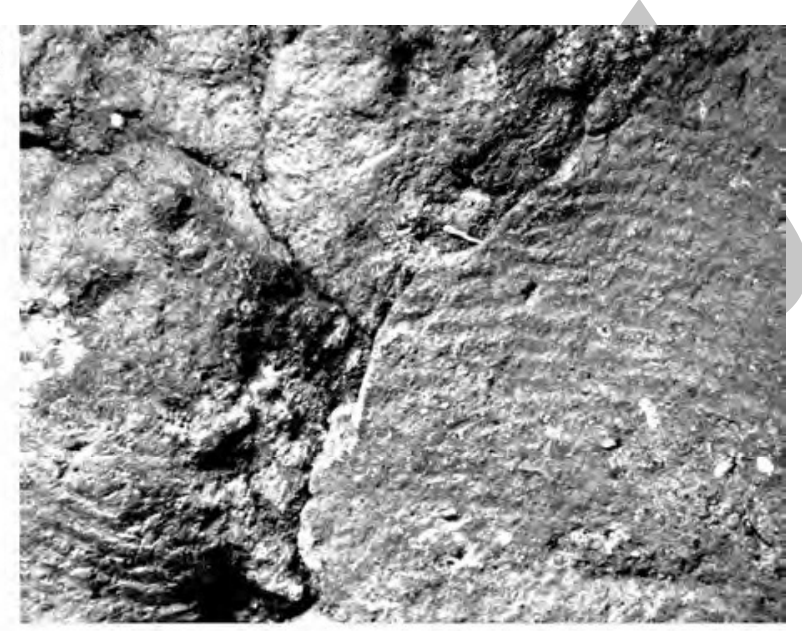

d

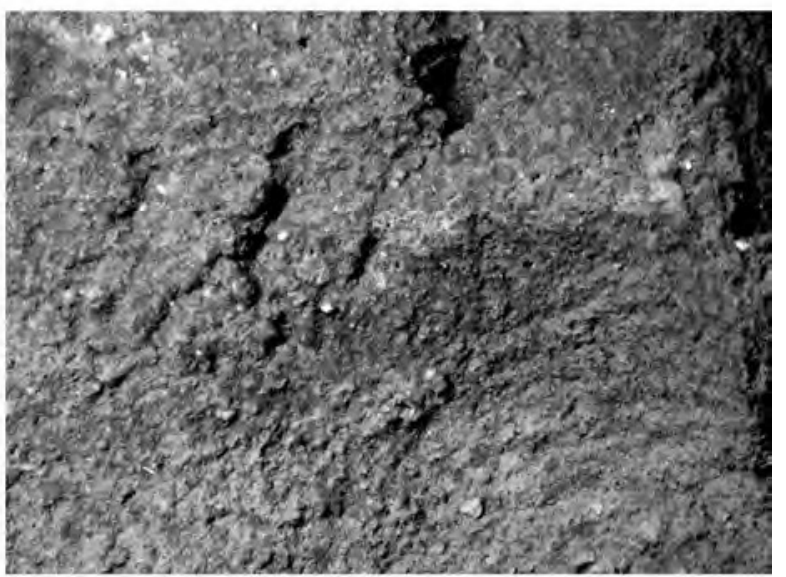

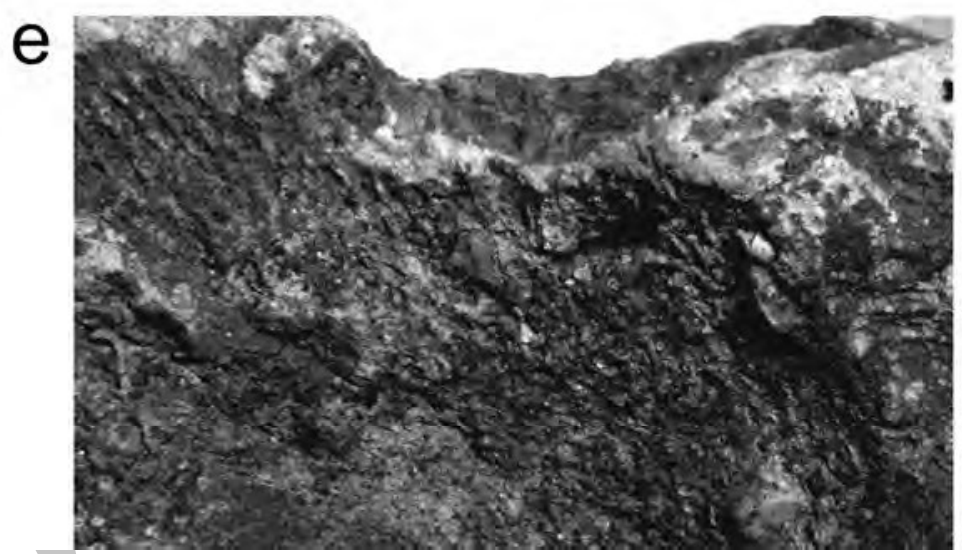

FIGURE 5: Friction ridge impressions on daub: a - from trench T, $\mathrm{b}$ - from trench $\mathrm{L}, \mathrm{c} \& \mathrm{~d}$ - from trench $\mathrm{X}, \mathrm{e}$ - from trench $\mathrm{H}$.

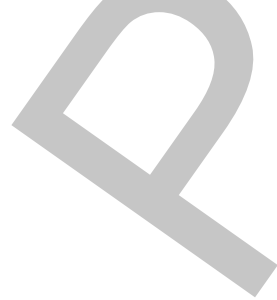


TABLE 1: List of information about analyzed daub fragments. Kamp, regression equation according to Kamp et al. (1999) modified by Králík (2000), age [months] = 614 * 1,08108 * ridge width [mm] - 112. L\&C, regression equation according to Loesch and Czyżewska (1972) modified by Králík and Novotný (2003), age [years] = (ridge width [ $\mu \mathrm{m}]$ * $1.261-344.24)$ / 11.94. K\&N, regression equation according to Králík and Novotný (2003), age [years] $=52.18087^{*}$ ridge width [mm] 7,89682 .

\begin{tabular}{|c|c|c|c|c|c|c|c|c|c|c|c|}
\hline \multirow[t]{2}{*}{ No. } & \multirow{2}{*}{$\begin{array}{l}\text { Location } \\
\text { of daub } \\
\text { fragment }\end{array}$} & \multirow{2}{*}{$\begin{array}{l}\text { Year of } \\
\text { excavation }\end{array}$} & \multirow{2}{*}{$\begin{array}{l}\text { Impressions } \\
\text { of structural } \\
\text { elements of } \\
\text { buildings }\end{array}$} & \multirow{2}{*}{$\begin{array}{l}\mathrm{N} \text { of ridge } \\
\text { impressions }\end{array}$} & \multicolumn{3}{|c|}{ Ridge width [mm] } & \multicolumn{3}{|c|}{ Estimated age [years] } & \multirow[t]{2}{*}{ Source } \\
\hline & & & & & $\begin{array}{l}\text { Weighted } \\
\text { mean }\end{array}$ & $\mathrm{N}$ & Range & Kamp & $\mathrm{L} \& \mathrm{C}$ & $\mathrm{K} \& \mathrm{~N}$ & \\
\hline 1 & Trench T & 1967 & yes & 1 & 0,383 & 4 & $\begin{array}{l}0.378- \\
0.387\end{array}$ & 11,9 & 11,6 & 12,1 & $\begin{array}{l}\text { Silska } \\
2012: \\
275 \text {, Fig. } \\
165\end{array}$ \\
\hline 2 & Trench L & 1966 & yes & 1 & 0,427 & 5 & $\begin{array}{l}0.393- \\
0.458\end{array}$ & 14,3 & 16,3 & 14,4 & - \\
\hline 3 & Trench X & 1967 & yes & 2 & - & - & - & - & - & - & - \\
\hline 4 & Trench H & 1965 & no & 1 & - & - & - & - & - & - & - \\
\hline
\end{tabular}

shorter on average than people living today and therefore their dermal ridges were narrower, it can be presumed that the estimated age is lower than the true age.

Furthermore, the amount by which daub shrinks when it dries or is fired is hard to determine. The used regression models allowed for a $7.5 \%$ change in the breadth of ridges caused by the shrinkage of the impression substrate (Králík, Novotný 2003). If, however, daub shrinks more than $7.5 \%$ (for example during the fire of a dwelling), the models will underestimate the age of the person who has left the impression. This possible error is, however, less significant than the error resulting from the imperfections of models which were discussed in the previous paragraph.

Finally, the present findings are made weaker, because it is not known which part of a hand left the impressions. It should be kept in mind that the models used in this study were as a rule developed for ridges on fingers and those on palm of the hand are broader (Cummins et al. 1941). If, therefore, the impressions were left by ridges on the palm, the models would overestimate the age of the persons who left them. It may be expected, however, that the error will not be significant.

\section{CONCLUSIONS}

Errors in the estimation of age for persons who left friction ridge impressions on daub from
Bruszczewo may cause their true age to be higher than estimated. In the case of person B, this may mean that he/she may have been even 16-17 years old (estimated age is 14-16 years) when body growth slows down or ends. Hence, this could have been a biologically adult person. Person A, in turn, can be rather safely considered as a youth. This conclusion is based, however, on the estimation method, and as such it should be treated with due caution, as there are several sources of error which may reduce estimate accuracy.

The study bears out the fact that children possibly could work at plastering wattles with daub in the walls of houses.

A significant supplement to the above results is offered by the characteristics of a burial recorded at the site (Kneisel 2010). It held the body of a male aged 18-24 years (Iwanek et al. 2010). A careful examination of the skeleton revealed lesions, testifying that the man had performed hard physical work for a long time (Iwanek et al. 2010). The man must have performed hard and monotonous work for a long time (from adolescence until death), involving in all likelihood lifting and carrying great weights on the right side of his body, possibly using a band fastened around his head. He must have also pulled great weights using a band wrapped over his right shoulder. The work was so hard and long that it caused lesions on the man's skeleton. What is more, in his childhood, he suffered periods of malnutrition. 
This data, albeit very modest, casts new light on the role of youth or, to some extent, also children, in prehistory, especially in the Early Bronze Age. Until now, the subject of childhood has been often left out of archaeological research (exceptions: Kamp 2001, Röder 2008). Assuming that in agricultural communities, it was children (below the age of 12 years) that represented 50 per cent of the population (Gross, Ruoff 1990, Röder 2008: 79), it may be claimed that they were an important pillar of the production economy and actively participated in some tasks carried out by the group. The results of the present study seem to suggest that the members of the community in question had to work hard since childhood.

\section{ACKNOWLEDGEMENTS}

This article is part of the implementation of $\mathrm{NCN}$ project no. 2014/15/G/HS3/04720.

\section{REFERENCES}

ÅSTRÖM P., 2007: The study of ancient fingerprints. Journal of Ancient Fingerprints 1: 2-3.

BIAŁEK I., RODZIŃSKA-NOWAK J., 1995: Ślady linii papilarnych na ceramice $\mathrm{z}$ okresu wpływów rzymskich, pochodzącej z osady kultury przeworskiej w Jakuszowicach, st. 2, woj. Kielce. Archeologia Polski 40, 1-2: 79-90.

BRANIGAN K., PAPADATOS Y., WYNN D., 2002: Fingerprints on Early Minoan pottery: A pilot study. The Annual of the British School at Athens 97; 49-53.

BLÁHOVÁ-SKLENÁŘ́VÁ Z., 2013: Nové doklady staveb starší doby bronzové ve východních Čechách. Živá Archeologie 15: 6-12.

CUMMINS H., WAITS W. J., McQUITTY J. T., 1941: The breadths of epidermal ridges on the finger tips and palms: A study of variation, American Journal of Anatomy 68: 127-150.

CUMMINS H., 1942: Ancient Finger Prints in Clay. Journal of Criminal Law and Criminology 32,4: 468-481.

CZEBRESZUK J., 2015: Únětice culture settlement in the mineralized zone of the site. In: J. Czebreszuk, J. Müller (Eds.): Bruszczewo III. The settlement and fortification in the mineral zone of the site, Studien zur Archäologie in Ostmitteleuropa, Studia nad Pradziejami Europy Środkowej, Band 13. Pp. 53-238. Poznań-Bonn.

CZEBRESZUK J., DUCKE B., MÜLLER J., SILSKA P., 2004: Siedlungsstrukturen und Siedlungstopographie/ Struktura i topografia osady. In: J. Czebreszuk, J. Müller (Eds.): Bruszczewo. Ausgrabungen und Forschungen in einer prähistorischen Siedlungskammer Großpolens,Badania mikro- regionu z terenu Wielkopolski. Band, Tom I. Forschungsstand - Erste Ergebnisse - Das östliche Feuchtbodenareal, Stan badań - Pierwsze wyniki - Wschodnia, torfowa część stanowiska. Pp 71-77. Poznań-Kiel-Rahden (Westf.).

CZEBRESZUK J., MÜLLER J., (EDS.) 2004: Bruszczewo: Ausgrabungen und Forschungen in einer prähistorischen Siedlungskammer Großpolens = badania mikroregionu osadniczego z terenu Wielkopolski, 1, Forschungsstand, erste Ergebnisse, das östliche Feuchtbodenareal = stan badań, pierwsze wyniki, wschodnia, torfowa część stanowiska. Poznań-Kiel-Rahden (Westf.).

CZEBRESZUK J., MÜLLER J., (EDS.) 2015: Bruszczewo III. The settlement and fortification in the mineral zone of the site, Studien zur Archäologie in Ostmitteleuropa,Studia nad Pradziejami Europy Środkowej, Band,Tom 13. Poznań-Bonn.

CZEBRESZUK J., MÜLLER J., SILSKA P., 2004: Forschungsgeschichte und Grabungs- verlauf/Historia badań stanowiska. In: J. Czebreszuk, J. Müller (Eds.): Bruszczewo: Ausgrabungen und Forschungen in einer prähistorischen Siedlungskammer Großpolens = badania mikroregionu osadniczego z terenu Wielkopolski, 1, Forschungsstand, erste Ergebnisse, das östliche Feuchtbodenareal = stan badań, pierwsze wyniki, wschodnia, torfowa część stanowiska. Pp. 13-35. Poznań-Kiel-Rahden (Westf.).

DĄBROWSKI J, MOGIELNICKA-URBAN M., 2004: Znaki nie utrwalone w glinie. Kilka uwag o tezach pracy A. Mierzwińskiego (2003). Archeologia Polski 49, 1-2: 125-129.

DREJER A., 2006: Gospodarka zwierzętami na wczesnobrazowej osadzie w Bruszczewie. Analiza weryfikacyjna materiałów osteologicznych z lat 60. XX wieku. Uniwersytet im. Adama Mickiewicza, Poznan. (unpubl. MA thesis)

FAULDS, H., 1880: On the skin-furrows of the hand. Nature 22: 605.

GROSS E., RUOFF U., 1990: Das Leben in neolithischen und bronzezeitlichen Dörfern am Zürich- und Greifensee. Archäologie der Schweiz 13, 2: 101-112.

HILDEBRANDT-RADKE I., 2010: Das geologische Alter und die Hauptphasen der Denudations- und Akkumulationsprozesse vor dem Hintergrund topografischer Verhältnisse des archäologischen Fundplatzes Bruszczewo/Wiek i główne fazy procesów denudacji i akumulacji w świetle uwarunkowań topograficznych stanowiska archeologicznego w Bruszczewie. In: J. Müller, J. Czebreszuk, J. Kneisel (Eds.): Bruszczewo. Ausgrabungen und Forschungen in einer prähistorischen Siedlungskammer Grosspolens, Badania mikroregionu osadniczego z terenu Wielkopolski. Band 2. Pp. 15-38. Bonn.

IWANEK B., PIONTEK J., NOWAK O., 2010: Anthropologische Analyse des Skelettes aus Bruszczewo/Analiza antropologiczna szkieletu z Bruszczewa. In: J. Müller, J. Czebreszuk, J. Kneisel (Eds.): Bruszczewo. Ausgrabungen und Forschungen in einer prähistorischen Siedlungskammer Grosspolens, Badania mikroregionu osadniczego z terenu Wielkopolski. Band 2. Pp.730-755. Bonn.

JAEGER M., 2015; Bronze Age Fortifications in Bruszczewo. In: J. Czebreszuk, J. Müller (Eds.): Bruszczewo III. The settlement and fortification in the mineral zone of the site, 
Studien zur Archäologie in Ostmitteleuropa, Studia nad Pradziejami Europy Środkowej, Band 13. Pp 405-412. Poznań-Bonn.

JAEGER M., 2016: Bronze Age Fortified Settlements in Central Europe. Studia nad Pradziejami Europy Środkowej, Studien zur Archäologie in Ostmitteleuropa, Band 17, PoznańBonn.

JAEGER M., STRÓŻYK M., 2015: Remains of buildings inside the settlement and daub finds in the mineral zone. In: J. Czebreszuk, J. Müller (Eds.): Bruszczewo III. The settlement and fortification in the mineral zone of the site, Studien zur Archäologie in Ostmitteleuropa, Studia nad Pradziejami Europy Środkowej, Band 13. Pp. 285-297. Poznań-Bonn.

JÄGERBRAND M., 2007: Documentation of fingerprints on ancient artefacts. Journal of Ancient Fingerprints 1: 19-25.

JÄGERBRAND M., LINDHOLM C. SJÖQUIST K.-E., 2006: Fingeravtryck på gropkeramik från Siretorp i Blekinge och Gullrum på Gotland. Fornvännen 101, 1: 9-17.

KAMP K. A., 2001: Where Have All the Children Gone?: The Archaeology of Childhood. Journal of Archaeological Method and Theory 8, 1: 1-34.

KAMP K. A., TIMMERMAN N., LIND G., GRAYBILL J., NATOWSKY I., 1999: Discovering childhood: using fingerprints to find children in the archaeological record. American Antiquity 64: 309-315.

KNEISEL J., 2010: Eine Siedlungsbestattung der Frühbronzezeit/ Pochówek na osadzie $\mathrm{z}$ wczesnej epoki brązu. In: J. Müller, J. Czebreszuk, J. Kneisel (Eds.): Bruszczewo. Ausgrabungen und Forschungen in einer prähistorischen Siedlungskammer Grosspolens, Badania mikroregionu osadniczego z terenu Wielkopolski. Band 2. Pp. 724-29. Bonn.

KRÁLÍK M., 2000: Otisky prstü a dlaní na keramickém materiálu (Fingerprints and palm-prints on ceramics). Department of Anthropology, Faculty of Science, Masaryk University Brno. (unpubl. MA thesis)

KRÁLÍK M., NEJMAN L., 2007: Fingerprints on Archeological Artifacts and Historical Items: Examples and Comments. Journal of Ancient Fingerprints 1: 4-15.

KRÁLÍK M., NOVOTNÝ V., 2003: Epidermal ridge breadth: an indicator of age and sex in paleodermatoglyphics. Variability and Evolution 11: 5-30.

KRÁLÍK M., NOVOTNÝ V., OLIVA M., 2002: Fingerprint on the Venus of Dolni Věstonice I. Anthropologie (Brno) 40, 2: 107-113.

KRÁLÍK M., URBANOVÁ P., HLOŽEK M., 2008: Finger, Hand and Foot Imprints: The evidence of children on archaeological artefacts. In: L. H. Dommasnes, M. Wrigglesworth, (Eds.):. Children, Identity and the Past. Pp. 1-15. Cambridge Scholars Publishing, Newcastle.

LASAK I., 1991: Uwagi o pozostałościach konstrukcji drewniano-ziemnych na osadzie wczesnobrązowej (stan. 22) w Radłowicach. Studia Archeologiczne 20: 24-45.

LOESCH D., CZYŻEWSKA J., 1972: Szerokość listewek skórnych na odcinku a-b na dłoni u dzieci w wieku 0-14 lat. Folia Morphologica 31: 249-254.

MIERZWIŃSKI A., 2003. Znaki utrwalone w glinie. Społecznoobrzędowe aspekty dziatań wytwórczych końca epoki brazu i wczesnej epoki żelaza. Model nadodrzański. Wrocław: Instytut Archeologii i Etnologii Polskiej Akademii Nauk.

MÜLLER J., CZEBRESZUK J., KNEISEL J. (EDS.) 2010 : Bruszczewo. Ausgrabungen und Forschungen in einer prähistorischen Siedlungskammer Grosspolens, Badania mikroregionu osadniczego z terenu Wielkopolski. Band 2. Bonn.

MÜLLER J., CZEBRESZUK J., JAEGER M., KNEISEL J (EDS.) 2015: Bruszczewo IV. Natural resources and economic activities of the Bronze Age people. Studien zur Archäologie in Ostmitteleuropa, Studia nad Pradziejami Europy Środkowej, Band 14. Poznań-Bonn.

OHLER E. A., CUMMINS H., 1942: Sexual differences in breadths of epidermal ridges on finger tips and palms. American Journal of Physical Anthropology 29: 341-362.

PEŠKA J., BERKOVEC T., HLOŽEK M., KRUPA P., TROJEK T., DROZDOVÁ E., KOLDÍNSKÁ Z., KRÁLÍK M., SELUCKÁ A., 2005: Dosavadní výsledky mezioborové spolupráce na nálezech ze starsi doby bronzové v Hulíně - U Isidorka. Ročenka 2004 Archeologické centrum Olomouc. Olomouc: Archeologické centrum Olomouc: 68-93.

PIECZYŃSKI Z., 1985: Umocnienia obronne osady z wczesnej epoki brązu w Bruszczewie, woj. leszczyńskie stan. 5. In M. Gedl (Ed.): Frühbronzezeitliche befestigte Siedlungen in Mitteleuropa. Pp. 167-179. Warszawa/Kraków.

PRIMAS M., 1975. Fingerabdrücke auf Keramik der Eisenzeit im Tessin. Archäologisches Korrespondenzblatt 5: 129-131.

RÖDER B., 2008: Archaeological childhood Research as Interdisciplinary Analysis. In: L. H. Dommasnes, M. Wrigglesworth (Eds): Children, Identities and the Past. Pp. 68-82. Cambridge Scholars Publishing, Newcastle.

SCHEFZIK M., 2006: Frühbronzezeitliche Gebäudeformen in Süddeutschland. Mit einer Gegenüber-stellung des Formenbestandes des östlichangrenzenden Kulturlandschafen. In: W. Blajer (Ed.): Z badań nad osadnictwem epoki brazu i wczesnej epoki żelaza w Europie Środkowej. Pp. 139-158. Kraków.

SCHEFZIK M., 2010: Siedlungen der Frühbronzezeit in Mitteleuropa - Eine Gegenüberstellung der Hausformen Süddeutschlands und des Aunjetitzer Kreises. In: H. Meller, F. Bertemes (Eds.): Der Griff nach den Sternen. Wie Europas Eliten zu Macht und Reichtum kamen. Internationales Symposium Halle (Saale) 16.-21. Februar 2005. Tagungen des Landesmuseums für Vorgeschichte Halle 5. Pp. 333-349. Halle/Saale.

SILSKA P., 2012: Wczesnobrazowa osada obronna w Bruszczewie. Badania 1964-1968, Bibliotheca Fontes Archaeologici Posnanienses, vol. 13, Poznań.

STRÓŻYK M., 2015: Early Bronze Age architecture. An attempt at a virtual reconstruction of the Bruszczewo defensive settlement. In: J. Czebreszuk, J. Müller (Eds.): Bruszczewo III. The settlement and fortification in the mineral zone of the site, Studien zur Archäologie in Ostmitteleuropa, Studia nad Pradziejami Europy Środkowej, Band 13. Pp. 383-404. Poznań-Bonn.

STUCHLÍK S., 2000: Nadzemní kůlové stavby ze starší doby bronzové na Moravě. Pravěk 10: 219-250. 
ZEITLER J. P., 2006: Häuser, Weiler, Dörfer - das Siedlungsbild in Süddeutschland im zweiten vorchristlichen Jahrtausend. In: W. Blajer (Ed.): Z badań nad osadnictwem epoki brazu i wczesnej epoki żelaza w Europie Środkowej. Pp. 173-190. Kraków.

Mateusz Stróżyk*

Poznań Archaeological Museum

ul. Wodna 27

61-781 Poznań

Poland

E-mail:

mateusz.strozyk@muzarp.poznan.pl

Szymon Matuszewski

Anna Mądra-Bielewicz

Laboratory of Criminalistics

Adam Mickiewicz University in Poznań

ul. Św. Marcin 90

61-809 Poznań

Poland

E-mail: szymmat@amu.edu.pl

E-mail:madan@amu.edu.pl

Janusz Czebreszuk

Institute of Archaeology, Faculty of

History

Adam Mickiewicz University in Poznań

ul. Uniwersytetu Poznańskiego 7

61-614 Poznań

Poland

E-mail: jancze@amu.edu.pl

Mateusz Jaeger

Institute of European Culture

Adam Mickiewicz University in Poznań

ul. Kostrzewskiego 5-7

62-200 Gniezno

Poland

E-mail: jaeger@amu.edu.pl

*Corresponding author. 